Original Article

\title{
Lumbriculus variegatus (Müller, 1774) (Oligochaeta, Lumbriculidae) in Campos do Jordão State Park, São Paulo, Brazil
}

\author{
Lumbriculus variegatus (Müller, 1774) (Oligochaeta, Lumbriculidae) no Parque Estadual \\ de Campos do Jordão, São Paulo, Brasil
}

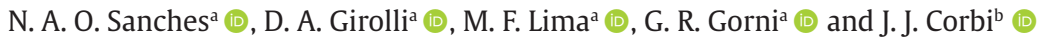 \\ aUniversidade de Araraquara - UNIARA, Programa de Pós-graduação em Desenvolvimento Territorial e Meio Ambiente, Araraquara, SP, Brasil \\ bUniversidade de São Paulo - USP, Escola de Engenharia de São Carlos - EESC, Departamento de Hidráulica e Saneamento, São Carlos, SP, Brasil
}

\begin{abstract}
The aim of this paper was recording the occurrence of the species Lumbriculus variegatus (Müller, 1774) (Oligochaeta, Lumbriculidae) in lotic systems of the State of São Paulo. Specimens were collected in Sapucaí River, located in Campos do Jordão State Park. The mapping of geographical distribution of this species is of interest to public health since L. variegatus may be an intermediate host of Dioctophyme renale (Goeze, 1782) (Nematoda, Dioctophymatidae), a parasite of recognized zoonotic potential. Distribution data serves as a basis for environmental monitoring and evaluation, being essential to map possible cases of the disease (Dioctophimosis) and provide information to health professionals.
\end{abstract}

Keywords: biodiversity, geographical distribution, aquatic macrofauna, public health, conservation unity.

\begin{abstract}
Resumo
O objetivo deste trabalho foi registrar a ocorrência de Lumbriculus variegatus (Müller, 1774) (Oligochaeta, Lumbriculidae) em um sistema lótico do Estado de São Paulo. Os espécimes foram coletados no rio Sapucaí, localizado no Parque Estadual de Campos do Jordão. O mapeamento da distribuição geográfica desta espécie é de interesse para saúde pública uma vez que L. variegatus pode ser um hospedeiro intermediário de Dioctophyme renale (Goeze, 1782) (Nematoda, Dioctophymatidae), parasito de reconhecido potencial zoonótico. Dados de distribuição servem de base para monitoramento e avaliação ambiental, sendo essenciais para mapear possíveis casos da doença (Dioctofimose) e fornecer informações para profissionais de saúde.
\end{abstract}

Palavras-chave: biodiversidade, distribuição geográfica, macrofauna aquática, saúde pública, unidade de conservação.

Oligochaeta is a group of macroinvertebrates distributed in freshwater systems that has gained prominence in water quality studies (Martin et al., 2008). These organisms have been used as bioindicators (Rodriguez and Reynoldson, 2011) and test organisms in ecotoxicology research (Vought and Wang, 2018; Leppänen and Kukkonen, 1998). Thus, knowing aspects of its ecology and geographical distribution becomes very important for the data production to be used as a basis for bioassessment research and for public health issues, since Lumbriculus variegatus (Müller, 1774) (Lumbriculidae, Clitellata) was identified in as the intermediate host of Dioctophyme renale (Goeze, 1782) (Nematoda, Dioctophymatidae) (Mace and Anderson, 1975). Dioctophyme renale has a worldwide distribution and can affect dogs, cats, wild mammals and even human (Mascarenhas et al., 2018) being characterized as zoonosis (Pedrassani and Nascimento, 2015). The life cycle of parasite occurs through the ingestion of eggs by Lumbriculus variegatus, which is the only intermediate host essential for the continuation of the cycle. After, the larva inside the egg develops until the infectious stage and can cause parasitosis in the definitive host when it feeds on the annelid or paratenic host, such as freshwater fish, crustaceans, frogs or salamanders (Figueiredo et al., 2013; Sapin et al., 2017).

Lumbriculus variegatus prefers shallow habitats, generally living on the banks of ponds, lakes, rivers and flood areas, where it feeds on decomposing vegetation, microorganisms and algae (Brinkhurst and Gelder, 1991; Marchese et al., 2015). Species is also found in reservoirs, mainly in microhabitats with plants and artificial substrates (plastic rubbish) (Dumnicka, 2007). It's common mainly 
in North America, Europe and Asia. In recent years it has been introduced in South America and can be considered according to Marchese et al. (2015) as an exotic species. Due to its rapid dispersion and adaptation, which causes its occurrence in some of its favorite habitats, such as layers of decomposing leaves, submerged trunks or sediments emerging vegetation base (Marchese et al., 2015). The present note aims to contribute to the expansion of knowledge of the $L$. variegatus distribution in the Neotropical region, through new record of this specie in Brazil, specifically in the State of São Paulo.

Campos do Jordão State Park is located in the municipality of Campos do Jordão and is part of the Serra da Mantiqueira, in the eastern portion of the State of São Paulo (Figure 1) (Schiavetti et al., 1997). Watercourses in the park belong to the Sapucaí-Guaçu river basin. Sapucaí River is of the fifth order and is located in mountainous regions, with cold, well-oxygenated, and transparent waters. Qualitative samplings were carried out in July 2014 with the use of a "D" net $(0.5 \mathrm{~mm}$ mesh) on the

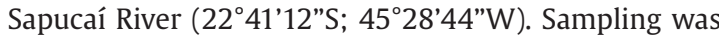
done by the Environmental Company of the State of São Paulo (CETESB). The organisms retained was fixed in site with formaldehyde, in sufficient volume to obtain a final concentration of $4 \%$. In the laboratory, the material was washed and transferred to $70 \%$ alcohol. For the identification of Oligochaeta, slides were prepared using lactophenol and observed under an optical microscope following the taxonomic key of Brinkhurst and Marchese (1989). We collected 432 oligochaetes that occurred in a preserved area, inside the park. On the day of data collection, the limnological characteristics of the site were: electrical conductivity $\left(55 \mu \mathrm{S} / \mathrm{cm}^{-1}\right)$, dissolved oxygen $\left(9.39 \mathrm{mg} / \mathrm{L}^{-1}\right)$ and cold waters $\left(10.7^{\circ} \mathrm{C}\right)$. But it is worth remembering that the collection stream has running water, which may have influenced the value of the dissolved oxygen.

According to Brinkhurst and Marchese (1989) L. variegatus is longer, broader and more robust than tubificids and some Enchytraeidae. They are similar to terrestrial worms, having only two chaetes in each segment, which are unicuspid or bifid with a very small upper tooth. In addition, the anterior region has the conical prostomium (Figure 2).

The first record of the species in Brazil, was in 2015 (Marchese et al., 2015) in an urban stream in Minas Gerais. However, the CETESB samples, identified in this research, were carried out in 2014, demonstrating that the species already occurred in continental aquatic environments in Brazil. This study recorded the first occurrence of $L$. variegatus in continental waters in the state of São Paulo and was the first record in preservation areas, with waters characteristic of clean environments, contrary to the record in Minas Gerais, in which the species only occurred in urban areas. Marchese et al. (2015) collected the species in warmer waters $\left(18.6-21.3^{\circ} \mathrm{C}\right)$, with lower oxygenation (3.3-8.6 mg/ $\left./ \mathrm{L}^{-1}\right)$ and higher conductivity $\left(84.2-97.1 \mu \mathrm{S} / \mathrm{cm}^{-1}\right)$.

Oligochaete occurs preferentially associated with decomposing leaves and other submerged plant or in the accumulated sediment at the base of the emerging vegetation (Drewes, 1999). Still, the species has a high dispersion capacity mainly because it forms cysts that can tolerate dehydration and low temperatures in the sediments (Marchese et al., 2015).

Marchese et al. (2015) emphasize the importance of mapping the geographical distribution of this species due to the risk of transmission of zoonosis, since L. variegatus

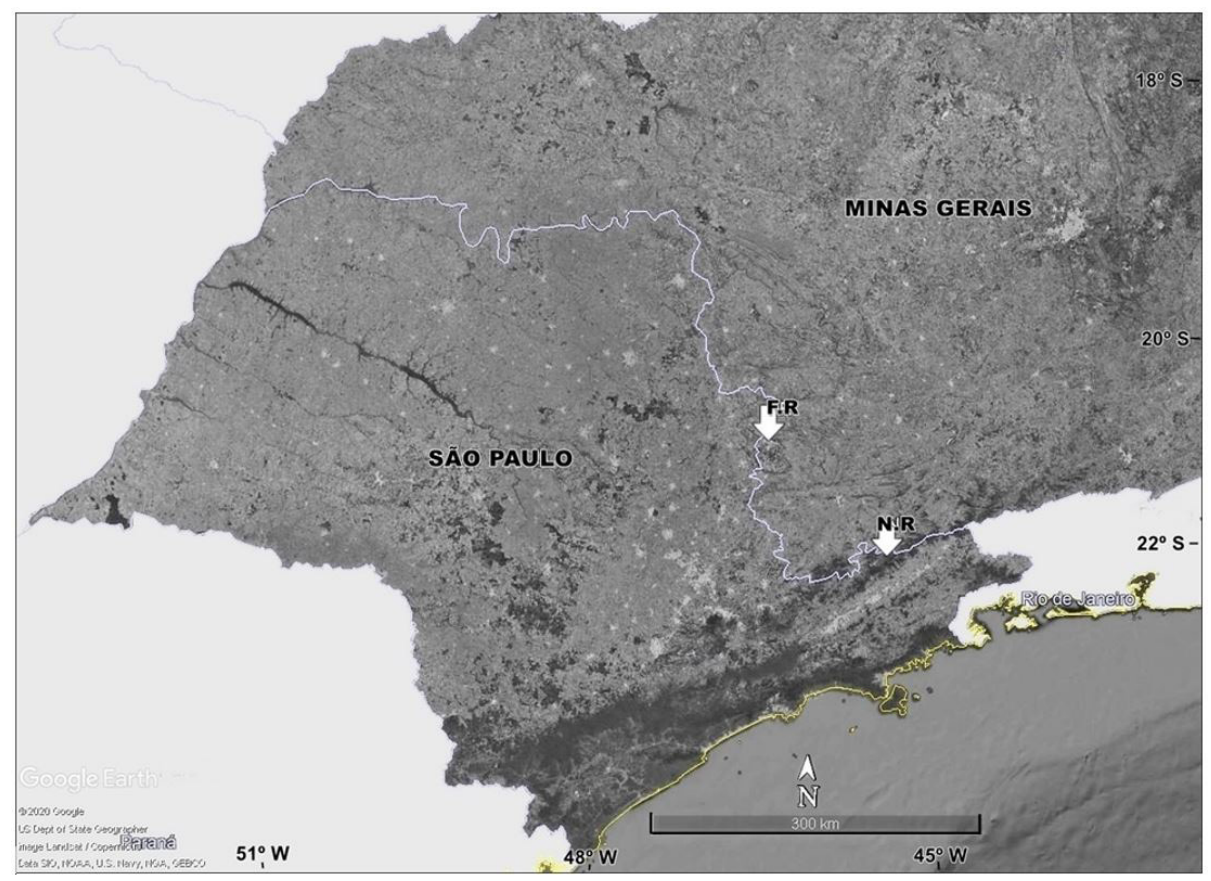

Figure 1. Distribution of Lumbriculus variegatus in Brazil. First record in Minas Gerais (F.R: First Record) and the new record in São Paulo (N.R: New Record). 

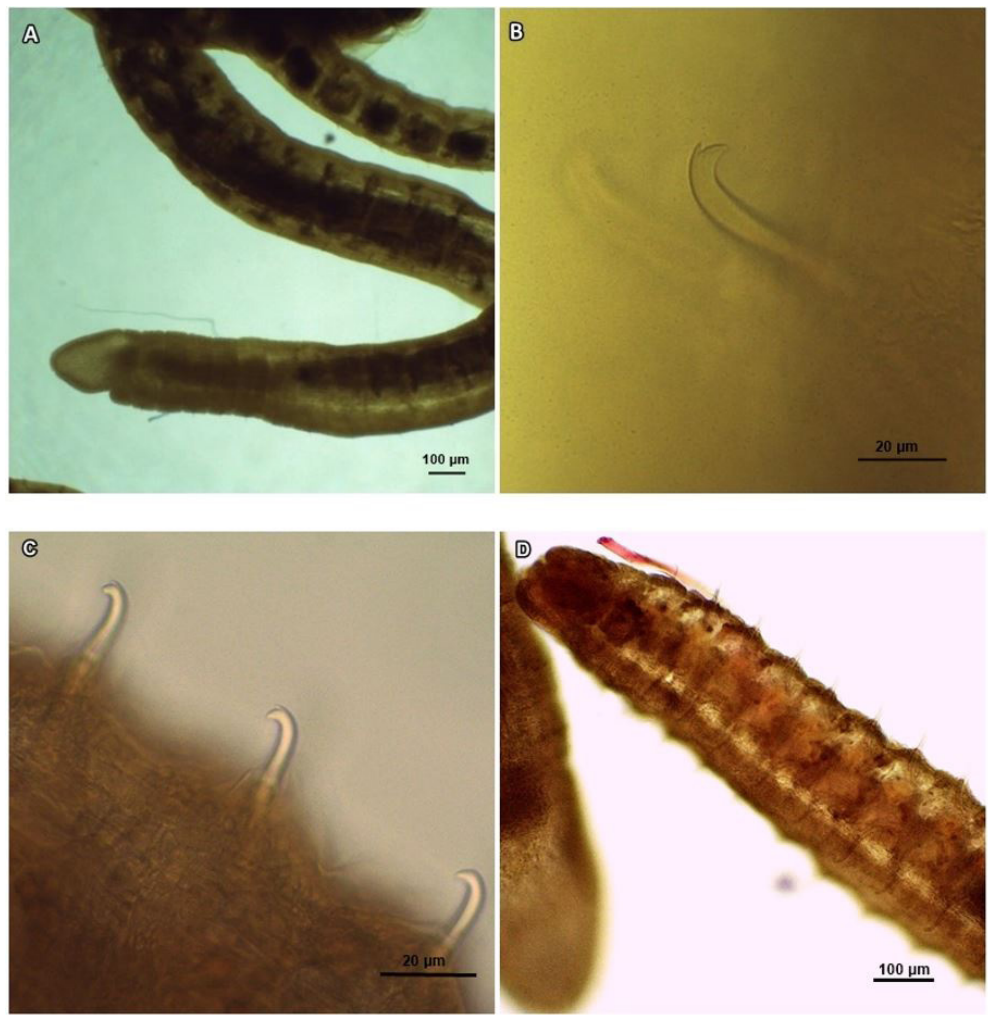

Figure 2. Lumbriculus variegatus. (A) Anterior region with a conical prostomium; (B) Bifid chaetes with reduced teeth; (C) Bifid chaetes of posterior region; (D) Posterior segments.

may be an intermediate host of the nematode parasite Dioctophyme renale. Eggs containing first stage larvae must be ingested by an $L$. variegatus, in which the development of the infective larva (third-stage larva). Therefore, the oligochaete isessential for the continuation of the cycle, since it acts as an intermediate host. Mammals (definitive hosts) become infected by ingesting oligochaetes through water (Mace and Anderson, 1975).

Moreover, Lumbriculus variegatus presents cryptic speciation (Gustafsson et al. 2009) and the realization of future molecular analysis on specimens found in Brazil (Minas Gerais and São Paulo) becomes necessary. In addition, the registration of species related to zoonosis, such as L. variegatus, is essential to map possible cases of the disease and provide valuable information for public health professionals and managers.

\section{Acknowledgements}

The authors are grateful to the Water Communities Sector (ELHC) of the Environmental Company of the state of São Paulo - CETESB, especially to the biologists Monica Luisa Kuhlmann and Hélio Rubens Victorino Imbimbo. This research was supported by FAPESP (São Paulo Research Foundation), Process Number 2018/12069-9 and by The Coordination of Improvement of Higher Education Personnel (CAPES).

\section{References}

BRINKHURST, R.O. and GELDER, S.R., 1991. Annelida: oligochaeta and branchiobdellida. In: J. H. THORP and A. P COVICH, eds. Ecology and classification of North American freshwater invertebrates. San Diego: Academic Press, pp. 401-428.

BRINKHURST, R.O. and MARCHESE, M.R., 1989. Guia para la identificación de oligoquetos acuáticos continentales de Sud y Centroamerica. Santa Fé: Asociación de Ciencias Naturales del Litoral, 207p.

DREWES, C.D., 1999. Helical swimming and body reversal behaviors in Lumbriculus variegatus (Annelida: Clitellata: Lumbriculidae). In: B. M. HEALY, T. B. REYNOLDSON and K. A. COATES, eds. Aquatic Oligochaetes. Dordrecht: Springer, pp. 263 269. http:// dx.doi.org/10.1007/978-94-011-4207-6_26.

DUMNICKA, E., 2007. Distribution of Oligochaeta in various littoral habitats in the anthropogenic reservoirs. Oceanological and Hydrobiological Studies, vol. 36, no. 1, pp. 13-19.

FIGUEIREDO, M.A.P., SILVA, D.F., MANRIQUE, W.G. and SOUSA, A.A.R., 2013. Ciclo errático de Dioctophyme renale: relato de dois casos. Orinoquia, vol. 17, no. 1, pp. 96-101. http://dx.doi. org/10.22579/20112629.54.

GUSTAFSSON, D.R., PRICE, D.A. and ERSÉUS, C., 2009. Genetic variation in the popular lab worm Lumbriculus variegatus (Annelida: Clitellata: Lumbriculidae) reveals cryptic speciation. Molecular Phylogenetics and Evolution, vol. 51, no. 2, pp. 182-189. http://dx.doi.org/10.1016/j.ympev.2008.12.016. PMid:19141324.

LEPPÄNEN, M.T. and KUKKONEN, J.V.K., 1998. Relative importance of ingested sediment and pore water as bioaccumulation routes 
for pyrene to oligochaete (Lumbriculus variegatus, Müller). Environmental Science E Technology, vol. 32, no. 1, pp. 15031508. http://dx.doi.org/10.1021/es970941k.

MACE, T.F. and ANDERSON, R.C., 1975. Development of the giant kidney worm, Dioctophyma renale (Goeze, 1782)(Nematoda: dioctophymatoidea). Canadian Journal of Zoology, vol. 53, no. 1a, pp. 1552-1568. http://dx.doi.org/10.1139/z75-190. PMid:127653.

MARCHESE, M.R., SANTOS, M.R., LIMA, J.D.S. and PAMPLIN, P.A.Z., 2015. First record of introduced species Lumbriculus variegatus Müller, 1774 (Lumbriculidae, Clitellata) in Brazil. BioInvasions Records, vol. 4, no. 2, pp. 81-85. http://dx.doi.org/10.3391/ bir.2015.4.2.02.

MARTIN, P., MARTINEZ-ANSEMIL, E., PINDER, A., TIMM, T. and WETZEL, M.J., 2008. Global diversity of Oligochaetous clitellates ("Oligochaeta"; Clitellata) in freshwater. Hydrobiologia, vol. 595, no. 1, pp. 117-127. http://dx.doi.org/10.1007/s10750-007-9009-1.

MASCARENHAS, C.S., PEREIRA, J.V. and MÜLLER, G., 2018. Occurrence of Dioctophyme renale larvae (Goeze, 1782) (Nematoda: Enoplida) in a new host from southern Brazil. Revista Brasileira de Parasitologia Veterinária, vol. 27, no. 4, pp. 609-613. http:// dx.doi.org/10.1590/s1984-296120180060. PMid:30427518.
PEDRASSANI, D. and NASCIMENTO, A.A., 2015. Verme gigante renal. Revista Portuguesa de Ciências Veterinárias, vol. 110, no. 593/594, pp. 30-37.

RODRIGUEZ, P. and REYNOLDSON, T.B., 2011. The pollution biology of aquatic oligochaetes. Dordrecht: Springer Science \& Business Media. http://dx.doi.org/10.1007/978-94-007-1718-3.

SAPIN, C.F., SILVA-MARIANO, L.C., GRECCO-CORRÊA, L., RAPPETI, J.C.S., DURANTE, L.H., PERERA, S.C., CLEFF, M.B. and GRECCO, F.B., 2017. Dioctofimatose renal bilateral e disseminada em cão. Pesquisa Veterinária Brasileira, vol. 37, no. 12, pp. 1499-1504. http://dx.doi.org/10.1590/s0100-736x2017001200022.

SCHIAVETTI, A., ROBIM, M.D.J. and MORAES, M.E.B., 1997. Parque Estadual de Campos do Jordão: avaliação quantitativa de visitação. Turismo em Análise, vol. 8, no. 1, pp. 13-20. http:// dx.doi.org/10.11606/issn.1984-4867.v8i2p13-20.

VOUGHT, V. and WANG, H.S., 2018. Impact of common environmental chemicals bisphenol A and bisphenol S on the physiology of Lumbriculus variegatus. Environmental Toxicology and Pharmacology, vol. 60, no. 1, pp. 225-229. http://dx.doi. org/10.1016/j.etap.2018.05.003. PMid:29763883. 